\title{
Organizational Qualitative Welfare Social by Quality System Audit
}

\author{
Nasser Fegh-hi Farahmand \\ Department of Management, Tabriz Branch, Islamic Azad University, Tabriz, Iran \\ E-mail: farahmand@iaut.ac.ir
}

Shirin Pour Haji Ali Farid

East Azerbaijan Behzisti Organization, Tabriz, Iran

E-mail: shirinfarid@ymail.com

Received: May 15, 2015

Accepted: May 27, 2015

Published: June 1, 2015

doi:10.5296/wjbm.v1i1.7731

URL: http://dx.doi.org/10.5296/ wjbm.v1i1.7731

\begin{abstract}
The importance of strategic, long-term policy and organizational qualitative welfare social is very clear to planners. Organizational development managers like to follow a similar and routine organizational development behavioral pattern. The aim of the study was to study about the impact of organizational qualitative welfare social strategy on creating a sustainable competitive advantage in the quality system audit. The current study was based on empirical approach. This article attempts to explain the organizational qualitative welfare social by quality system audit by patterns of thinking. This paper reviews organizational qualitative welfare social and organizational development measurement literature. However, this study concluded that the performance of the organization is highly affected by its organizational qualitative welfare social strategy and developed manager's creativity. In organizations, where an organizational qualitative welfare social exists, the preparation of the organizational development managers may have been driven by external forces.
\end{abstract}

Keywords: Quality system audit, Quality system audit, Organizational qualitative welfare social 


\section{Introduction}

The complexity of this environment stems from the fierce competition, the deregulation policy, the removal of restrictions between banks, building societies and insurance companies and the vast expansion in the adoption and use of information technologies. For organizations to be organizational qualitative welfare social strategy, they had to improve their working environment and delegate their employees more authorities by quality system audit. This in return has created unprecedented challenges in developing and presenting new service products which are highly successful and competitive. Such complexity has also influenced the used applications and techniques in producing and organizational qualitative welfare social such products. Therefore, developed manager's institutions are trying more than any other time to create a sustainable competitive advantage compared to other competitors in order to secure their market share and enhance their presence in the quality system audit market. It guides the manager in a way that avoids the organizational qualitative welfare social quality system audit synergy with organizational development managers' which results in sub-optimization of the performance measurement portfolio. In an environment characterized by high-velocity change, short product life cycles, mass customization, narrowing customer niches, the successful integration of technological and organizational qualitative welfare social capabilities for a given product conveys little long term strategic advantage to organizations. More specifically, in the quality system audit, the business quality system audit environment has become highly complex, competitive and dynamic.

The organizational qualitative welfare social should be the primary determinant of an organization's organizational qualitative welfare social quality system audit synergy with organizational development managers' framework. A fundamental proposition in organizational qualitative welfare social is that it must be aligned with customers and competitive advantage. Unfortunately, organizational qualitative welfare social performance measurement literature has provided ambiguous guidance to organizational development managers. The organizational qualitative welfare social characteristics showing a significant association with a commitment to organizational qualitative welfare social and quality system audit showed a positive association with that quality system audit with a growth orientation.

\section{Organizational Qualitative Welfare Social}

The integration between market segmentation continuation and organizational qualitative welfare social quality system audit synergy with organizational development managers' should enhanced. By means of this argumentation, it is shown that organizational qualitative welfare social fulfills all requirements that are needed to talk about strategic valuable resources in the perspective of the organization. Further, organizational qualitative welfare social generates the benefit of reducing the probability of entry of competitors and a jointly enhanced market reputation. An appropriately managed organizational qualitative welfare social constitutes a crucial factor for success in the market. This is not just a hypothesis but an often-proved fact in day-to-day business. Requirements such as uniqueness and immobility could be proven as fulfilled. The most important aspect of organizational qualitative welfare social due to immobility is the featuring of an inherent isolation 
mechanism which results from the essential partnership with the organization. This feature is directly linked to the not respectively heavily imitable condition of an organizational qualitative welfare social. The most obvious of these are the requirements of external agencies providing funding for either start up or expansion. However, the organizational qualitative welfare social may serve as a strategic planning document for the managers, entrepreneurs and educated workers, a plan to guide the organizational development and serve as a basis for taking strategic decisions and also it may serve as a subsequent monitoring device.

The strategically aligned framework for clearer logic behind actions for more appropriate organizational qualitative welfare social quality system audit synergy with organizational development managers' should result in less internal conflict. The performance portfolio that discriminates between performance measures in order to avoid suboptimal performance. Quality system audit need clarity in determining the difference between efficient and effective performance measures.

In other words, improving one performance measure can adversely affect other performance measures where a comprehensive framework is not used. The set of guidelines to ensure organizational qualitative welfare social developed manager's synergy with organizational development managers' synergies are achieved in the targeting of high and low customer lifetime value segments.

The organizational qualitative welfare social quality system audit with various network partners is critically important for organizational development managers. Synergistic effects of the cooperation of various network participants also constitute a critical determinant for success. The organizational qualitative welfare social therefore cannot be imitated without the interdependences within the cooperating companies. However, that is where path independency ensues. In order to be effective, a final demand on competitive efficient resources is needed, which is the claim for not being substitutable. As seen previously, substitution of strategic relevant resources faces different barriers and difficulties which originate in organizational routines. Organizational qualitative welfare social cannot be substituted because of the brand-specific effects. The final outcome of this argumentation is that organizational qualitative welfare social has to be seen as strategic valuable resources. However, organizational qualitative welfare social would be void without appropriate management.

The organizational qualitative welfare social is proven to be a strategic resource and therefore a core competence which requires the management of such. Organizational development managers are proven to be core competencies due to the constant quality system audit of advantages. This begins as the brand develops and continues to the managing and controlling phases and finally until the adjustment to new market requirements. One area of brand managerial responsibility is the relationship with the downstream partners.. This is an additional competence in contrast to end-user or business brand management that is demanded. It is not only organizational development managers that require brand management competency, but also organizational development manager, who would require 
some more specific skills, because of its complexity.

Further research should close this gap by first developing a theoretical basis which should involve all aspects of organizational qualitative welfare social quality system audit such as the network, the information exchange, the partnership relation, the interaction of different brand profiles and so on. Without such a theoretical framework, the development of management strategies has to stay out of stable basic. In order to achieve organizational development success, it is important to understand the relationship between organizational qualitative welfare social planning by organizational development managers and continuation deployment success.

As management itself becomes more emphatically fast-paced and intuitive, in order to deal with complexity and unpredictability, research is beginning to accumulate showing that coaching formats used in management support are more effective than training in the older logical comprehensive pursuits. A central motivation for this has been the public uneasiness towards many of the applications of gene organizations technology, as well as the general distrust of the public towards officials, scientists and representatives of organizations in the management of risks. Organizational development management would then accomplish the required attributes which are generally made on core competences. With this paper we could illustrate, that, in the case of organizational development management, the organizational qualitative welfare social quality system audit is an adequate management theory to explain the phenomenon organizational qualitative welfare social as a strategic resource and therefore core competence.

As discussed in the introduction, research broached the issue of organizational qualitative welfare social quality system audit over a few decades without developing a management model or any useable approach that allowed transferring insights from research to real business. In many related disciplines, research had provided explanations of business phenomena which built the centre of continuation development and in the end to a derivation of action alternatives. This was the missing factor in the case of organizational qualitative welfare social quality system audit.

\section{Organizational Development Managers}

The organizational qualitative welfare social mix could be also argued that as long as organization organizational qualitative welfare social practices, goods and services reflect its presence in the present time, then the strategy process by its definition and nature will be the only path to the future.

A selection of the organizational development manager is the potential to influence an organization propensity to undertake organizational qualitative welfare social factors quality system audit. Moreover, in order to foster strategy and enhance organizations' performance in the quality system audit, organizations are required to increase their reliance on the external knowledge through extending their knowledge milieu. This, however, may contribute in upgrading the learning process of the organization in question and increase its ability on creating a sustainable competitive advantage. The strategy process in presenting new quality 
system audit products has become an antecedent condition to enhance the growth of the developed manager's institutions and face the imposed threats and pressure from the external environment. The importance of organization's external environment stems from the fact that a organization's strategy process is embedded in an environmental context. Furthermore, as developed manager's offerings are hard to be distinguished among competitors, it is argued that developed manager's institutions should use the process of strategy as a platform to achieve unduplicated competitive advantage. This may occur through the continuous screening of a organization internal resources in order to identify their weaknesses and strengths and based on that, the organization might be able to develop dynamic resources and capabilities which are characterized. The nature of the organizational development managers is seen as critical in other aspects of the activities of organization.

Therefore, organizational qualitative welfare social mix strategy represents a strategic vision for quality system audit institutions which depend on a strategic ideology as a way to planning their future quality system audit activities. As a result of that, organizational qualitative welfare social mix strategy might help organizations in mitigating the turbulence of the external environment and lead organizations to be pioneer in their field. The organizational qualitative welfare social strategy is also required to decrease organization competitors' ability and capacity to imitate and to increase casual ambiguity. Based on that, quality system audit institution might achieve a superior advantage and performance due to the better understanding of customer needs and this in return, will raise the bar of competition and enable the strategy organization to tailor a distinguished organizational qualitative welfare social mix, unlike competitors.

Predictions of the direction in which the variables will operate are inevitably problematic as there is little prior work on the determinants of organizational qualitative welfare social upon which organizational development managers can draw by:

1) Developed manager's ability: This variable identified as important in a number of studies.

2) Quality system audit' experience: It may be strongly linked to ability and it could be argued that it might work in two ways. A long number of years running an organization as organizational development manager might increase a propensity to plan future directions for the organizational development or indeed, once the initial phases had passed and funding secured planning might well be less of a priority.

3) quality system audit' education level: In the context of organizational qualitative welfare social quality system audit, this variable might seem reasonable to hypothesis that the more highly educated organizational development managers will tend to be more aware of the desirability of organizational qualitative welfare social and thus, organization run by the better educated organizational development manager.

4) Quality system audit' innovation: A distinction here may be drawn between those for whom the current organization is their first and serial founders.

The changing view of organization's strategic vision regarding organizational qualitative welfare social strategy and creativity and the incremental investment in the organization has 
also contributed widely in overcoming one of the sever problems that faces many organizations. This particular problem is related the inability to secure a company's market share and maintain market presence. The presence of pioneering organizations is highly remarkable in the business environment due to the speed in improving existing products and the introduction of new and novel products to the market.

The process of organizational qualitative welfare social strategy may also reflect the exemplification of organization ability to use uncommon and nontraditional ways to achieve or produce certain thing which basically contain the characteristics of originality. Other scholars referred to the process of organizational qualitative welfare social strategy as the organization's early adoption/usage of new ideas in comparison to competitors in a specific industry.

\section{Organizational Development Manager's Performance}

In order to understand whether the organizational development managers is performing or not, organization need to ensure that the organizational development managers is appropriate for each organizational qualitative. In response to this research gap, can investigates whether organizational development managers should differ according to organizational qualitative welfare social. Quality system audit were asked whether or not they had a formal organizational qualitative welfare social quality system audit for their organization and the period of time to which it applied. Over half organizational development managers had no such plan which fits well with the common perception of the lack of planning in small organization. Clearly, organizational qualitative welfare social is not a feature of the majority organization, at least not within this sample of organization within this location. The organizational qualitative welfare social strategy and creativity is the key success for organizations in business environment, particularly in strategic planning for future growth and for developing new products and services. The organizational qualitative welfare social strategy reflects the organization ability to improve products/services continuously, which lead to achieve huge and new benefits to its clients and satisfy their needs in a unique way. This in return, may result in creating a competitive advantage for the organization in question through identifying needs and translating them into technical specifications and distinguishing the organization from its competitors by making the organization presence remarkable. The authors also refers to the organizational qualitative welfare social strategy process as the continuous continuations of the organizational learning process and conducting new and modern organizational qualitative welfare social activities and practices which are superior compared to the traditional ones.

The characteristics of the organizational development managers of the sample organization are reviewed. The organizational development managers ranged in ability from low to high. In view the ability of most of the quality system audit, just over half had been controlling their organization for five or more years. Their formal educational levels tended to be high. Amongst these organizational development managers, a distinction could be drawn between and those for whom their current organizational development was their first organization and the majority were novice organizational development managers. Regardless of the educated 
workers, a significant number had gained organizing before setting up their own organization. They can be contrasted with the remainder of the sample group who had been working more directly in production. A striking feature of these organizations perhaps not surprising in organization based mainly on traditional industries is that 61 percent of the organizational development managers had grown up in industrial area.

Clearly, within this group, there is a sub set of growth oriented quality system audit whose propensity to undertake organizational qualitative welfare social quality system audit might be contrasted with those who were content with their current level of organizational development. The latter may well belong to that group of organizational development managers often characterized as running lifestyle organization. From this overview of the selected organizational development manager's characteristics and the strategies of the sampled organization, it is now possible to explore the extent to which these differing characteristics and strategies influence whether or not an organization engages in organizational qualitative welfare social. For quality system audit, the organizational qualitative welfare social performance measurement is an area that represents a significant opportunity for business investment and management attention.

The interdisciplinary conceptual model will provide guidance to organizational development managers in developing contextually relevant organizational qualitative welfare social measures. It is important to stress that this study is confined to a sample of the organizational development managers of organization in one part of the area of market potential. Further, the characteristics which have been measured can be grouped into environmental and organizational qualitative welfare social variables rather than those variables which measure attributes of the personality of the organizational development managers. It is also recognized that the relationships only significant at a relatively low level but this reflects, in part, the small size of our initial sample. Therefore useful conclusions about organizational development managers' performance can be drawn as follows:

1) Quality system audit undertake: Organizational qualitative welfare social is a characteristic of the organization that there still remains a high proportion of quality system audit of organization who does not undertake organizational qualitative welfare social quality system audit. Quality system audit' characteristics and organizational qualitative welfare social variables can be an influence upon whether or not small organization undertakes organizational qualitative welfare social quality system audit when controls have been introduced for sector and size.

2) Quality system audit' characteristics: The key quality system audit characteristics, associated with a greater tendency to undertake organizational qualitative welfare social by quality system audit, are a higher level of education level, experience and running organizational development.

3) Quality system audit' experience: There was no evidence that previous management experience was linked to a higher propensity to organizational development plan. That developed manager with management experience is somewhat cynical of the value of paper exercises and the writing of organizational development plans. 
The organizational qualitative welfare social strategy process is influenced by the following inter correlated parts as organizational structure and processes, suppliers' organizational structure and processes and structure and processes of buyer-supplier interfaces. Quality system audit' interest success is most likely to come from approaches to those quality system audit with the characteristics of planners but who are not yet planners. These are the quality system audit who may be unaware of the benefits of organizational qualitative welfare social rather than outwardly hostile. However, developed manager's characteristics are rarely in the public domain so such targeting becomes difficult.

\section{Organizational Qualitative Welfare Social Factors}

The organizational qualitative welfare social strategy process requires proficiency in all organizational functions. However, the ability to develop new products, as a response to changes in customer needs, is not sufficient enough for an organization to have a competitive advantage. The concept of organizational qualitative welfare social strategy should contain characteristics as fluency, flexibility, originality, problem sensation and realization and elaboration. Moreover, the , organizational qualitative welfare social strategy may represent a weapon of differentiation, novelty, new combination, top first move and the ability to discovering new opportunities. In addition the types and the importance of , organizational qualitative welfare social strategy according to product types, organization types, the aim of , organizational qualitative welfare social strategy and customer types and nature.

Furthermore, it is demonstrated that requirements should be taken into consideration in the process of organizational qualitative welfare social strategy, namely; managerial and organizational requirements; requirements regarding the individuals who work in both organizational qualitative welfare social, requirements regarding the organizational qualitative welfare social information and regarding the benefits of organizational qualitative welfare social strategy and creativity. Organizations organizational qualitative welfare social successful at continuation quality system audit effectively manages six key supporting factors:

1) Organizational qualitative welfare social action planning: Organizations organizational qualitative welfare social successful at implementing continuation develops detailed action plans chronological lists of action steps which add the necessary detail to their strategies. Moreover, assign responsibility to a specific individual for accomplishing each of those action steps. In addition, they set a due date and estimate the resources required to accomplish each of their action steps. Thus, they translate their broad continuation statement into a number of specific work assignments.

2) Organizational qualitative welfare social structure: Those successful organizational qualitative welfare socials at implementing continuation give thought to their organizational structure. The reason the organization had been unable to develop those products was simple. Lacking the necessary commitment for new product development, management did not establish an R\&D group. Rather, it assigned its manufacturing engineering group the job of new product development and hired two junior engineers for the task. Since the primary function of the organizational engineering group was to keep the organization humming, 
those engineers kept being pulled off their new product or services projects and into the role of the manufacturing support.

3) Organizational qualitative welfare social human resources: Organizations successful organizational qualitative welfare social at continuation quality system audit consider the human resource factor in making strategies happen. Further, they realize that the human resource issue is really a two-part story. First, consideration of human resources requires that management think about the organization's communication needs. That they articulate the strategies so that those charged with developing the corresponding action steps fully understand the continuation they are to implement.

Managers successful at organizational qualitative welfare social quality system audit are aware of the effects each new continuation will have on their human resource needs. Monitoring and controlling the organizational qualitative welfare social plan includes a periodic look to see if you are on course. It also includes consideration of options to get continuation once derailed back on track. Those options about organizational qualitative welfare social include changing the schedule, changing the action steps and tactics, changing the continuation or as a last resort changing the objective. It is not enough to manage one, two or a few continuation supporting factors. To successfully implement your strategies, organizations have gone to manage them all. Moreover, make sure you link them together. In the quality system audit, strategy products represent the organization's ability to innovate and present new and novel product or develop existing products to satisfy client needs. This could be done through the use and adoption of new technology, organizational development information technology and the internet. Strategy, in quality system audit, may also represent the introduction of organizational development information technology such as balance from different parts of the world. For the developed manager's institutions to be strategy, they are required to create an organizational development communication in which information is collected from multiple sources, analyzed, understood and acted on in order to foster strategy. Thus, the organization can offer the product at a higher price, achieve greater market share and, thereby, maximize its sales revenues accelerating product development.

\section{Organizational Qualitative Welfare Social by Quality System Audit}

The organizational qualitative welfare social strategy in the quality system audit improves the organizational development of the developed manager's products, increases flexibility to be effective and compresses time to market. The benefits of organizational qualitative welfare social strategy in the quality system audit depends on the perceived value of the quality system audit products and hence, strategy organizations which continuously improve their quality system audit products would result in enhancing the organization's reputation, corporate image and the perceived value of the product. The concept of organizational qualitative welfare social strategy from a developed manager's perspective has been given far less attention. Specifically, as far as the organizational qualitative welfare social knowledge is concerned that focus on evaluating the impact of the strategy process on quality system audit particularly. Therefore, the purpose is to evaluate the extent to which organizational qualitative welfare social strategy may help organizations on creating a sustainable 
competitive advantage. The central mission of organizations activities under the enlightenment model is to raise the organizational qualitative welfare social quality system audit level of the organization. The organizational qualitative welfare social by quality system audit is possible by organizational qualitative welfare social mission: The mission of organization is organizational development instrumental is an endemic needed for increasing organizational development effective communication. Thus, the inclusion of the in the organizational development structures of organization decision-making is neither principally refuted nor taken as a point of departure. The organizational development person's empowerment of sustainable decision-making is core values, to which increasing public participation is though to be a most appropriate means. Keeping in view these broad objectives, it is essential to spell out an quality system audit organizational qualitative welfare social quality system audit that will enable identification of specific plans, programs and projects, with clearly defined tasks, estimates of necessary resources, and time targets. Some of the key elements of the developed manager's continuation are as follows:

- Continuation: Suitable mechanism will be evolved by which independent inputs on science organizational qualitative welfare social and planning are obtained on a continuous basis from a wide cross section of science organizational qualitative welfare social. It will utilize the academies and specialized professional bodies for this purpose. These inputs will form an integral part of the organizational development planning and quality system audit of all programs relating to science organizational qualitative welfare social, as also in government decision making and formulation of policies in organizational development sectors.

- Integration: The greater integration of the programs in organizational development with science organizational qualitative welfare social activities will go a long way in ensuring a wider, more visible and tangible impact. This will call for a certain percentage of the overall allocation of each of the science organizational qualitative welfare social to be devoted for relevant programs. The organizational qualitative welfare social quality system audit is necessary to infuse a new sense of dynamism in our science organizational qualitative welfare social. The science organizational qualitative welfare social departments, agencies and other academic institutions, including universities i.e. the science organizational qualitative welfare social system as a whole, would be substantially strengthened, given full autonomy and flexibility, and de-bureaucratized. It will be ensured that all highly organizational qualitative welfare social quality system audit are run by science organizational qualitative welfare social. All the major organizational development planning will have high-level scientific advisory mechanisms.

- Formulating: Organization organizational qualitative welfare social will ensure continued existence of organizational qualitative welfare social by quality system audit which will assist in formulating and implementing various programs and policies. It will have appropriate representation of organization leaders, leading science organizational qualitative welfare social and various scientific departments. Organization will make necessary commitments for higher education and science organizational qualitative welfare social. It will, through its own resources and also through contribution by organization, raise the level of investment on science organizational qualitative welfare social by the end of the plan. For this, it is essential 
for organization to steeply increase its investments in organizational qualitative welfare social quality system audit. Science organizational qualitative welfare social is advancing at a very fast pace, and obsolescence of physical organizational development infrastructure, as also of skills and competence, take place rapidly.

- Involving: The demand is bound to increase in the coming years with more intensive activities involving science organizational qualitative welfare social. There is need to progressively increase the rate of generation of high organizational development skilled at all levels. This process would naturally entail reversing the present flow of organizational development talent away from science organizational qualitative welfare social by strategy schemes. For building up the science organizational qualitative welfare social base in relevant areas, the agencies and departments concerned with science organizational qualitative welfare social will make available substantial funding from their allocation. Flexible organizational development mechanisms will be put in place in organization and organizational environment to enable organizational development researchers to change fields and bring new inputs into traditional disciplines.

A strong base of science organizational qualitative welfare social provides a crucial foundation for a vibrant program of science organizational qualitative welfare social development. Priority will be placed on the development of science organizational qualitative welfare social which address the basic needs of the population; make organizational competitive and make the economically organizational development strong. Special emphasis will be placed on equity in development, so that the benefits of science organizational qualitative welfare social growth reach the majority of the population, particularly the disadvantaged sections, leading to an improved organizational development of life for every citizen of the organization. These aspects require science organizational qualitative welfare social foresight, which involves not only forecasting and assessment of technologies but also their organization and organizational environment environmental consequences. The science organizational qualitative welfare social will be launched to develop strategy science organizational qualitative welfare social of a breakthrough nature; and to increase our share of high-tech products. Aggressive international benchmarking will be carried out. Simultaneously, efforts will be made to strengthen traditional industry so as to meet the new requirements of competition through the use of appropriate science organizational qualitative welfare social. This organization is particularly important as it provides employment at lower per capita investment, involves low energy inputs, and carries with it unique civilization traditions and culture. Value addition and creation of wealth through reassessment, redistribution and repositioning of our intellectual, capital and material resource will be achieved through effective use of science organizational qualitative welfare social.

A comprehensive science organizational qualitative welfare social system will be created covering science organizational qualitative welfare social as also legal, financial and other related aspects. There is need to change the ways in which organizational development performs, if innovation has to fructify. Every effort will be made to achieve synergy between science organizational qualitative welfare social and scientific research. Increased encouragement will be given, and flexible mechanisms will be evolved to help, science 
organizational qualitative welfare social to transfer the know-how generated by them to the industry and be a partner in receiving the financial returns. Organization will be encouraged to financially adopt or support educational and research institutions, fund courses of interest to them, create professional chairs etc. to help direct organization towards tangible organizational goals.

Development of science organizational qualitative welfare social adds value to organizational resources and which provide holistic and optimal solutions. Science organizational qualitative welfare social has an important role in any general continuation to address the problems of management of the impacts of natural hazards. A concerted action plan to organizational development enhances predictive capabilities and preparedness for meeting emergencies will be drawn up. Measures will be undertaken to promote research on natural phenomena that lead to science organizational qualitative welfare social activities that aggravate them. This will be with a view to developing practical science organizational qualitative welfare social.

Organization must be able to consider the implications of emerging science organizational qualitative welfare social. The science organizational qualitative welfare social development can benefit greatly by cooperation and collaboration. Common goals can be effectively addressed by pooling both material and intellectual resources. Science organizational qualitative welfare social programs will be encouraged between organizations. Effective science organizational qualitative welfare social and reviewing mechanisms will be significantly strengthened, and wherever not available will be put in place. It will be ensured that the scientific community is involved in, and responsible for, smooth and speedy quality system audit.

\section{Conclusion}

The ability of organizational qualitative welfare social knowledge acquisition and utilization were decisive for strategy activities and success of quality system audit institutions.In particular, the tackles in a specific way the impact of strategy in organizational qualitative welfare social, management perception and support for the process of organizational qualitative welfare social strategy, customer perception and involvement in the process of organizational qualitative welfare social strategy and strategy in organizational qualitative welfare social information, on the potential of creating a sustainable competitive advantage for quality system audit institutions. Additionally, the existing knowledge by drawing and systematically synthesizing literature from disparate organizational qualitative welfare social disciplines, thus, develops a approach.. This approach is designed and developed to measure the impact of organizational qualitative welfare social strategy on creating a sustainable competitive advantage.

The process of organizational qualitative welfare social knowledge development requires the acquisition of useful information, the dissemination of the acquired knowledge and its effective utilization in organizations' strategy activities. In addition, a significant correlation of organizational qualitative welfare social knowledge acquisition, dissemination and utilization with the quality system audit intensity and strategy performance. The difficulty in long-term organizational development planning is also due to the rapid and unpredictable 
evolution of science organizational development, making it very hazardous to forecast development beyond a period. Organizational development planning in organizations acquired an impetus with long-term policy statements, such as organizational development vision. A science organizational development vision provides the wanted scenario to strive for, the end point of a long-term policy. However, the developed manager's vision must be accompanied by a roadmap to allow the journey which starts now, to reach the required destination in the future. Steps will be taken to network the existing infrastructure, investments and intellectual strengths, wherever they exist, to achieve effective and optimal utilization, and constantly upgrade them to meet changing needs. Organizational development strategies require linkage both vertically and horizontally. Vertical linkages establish coordination and support between corporate, divisional and departmental plans. For example, a divisional organizational qualitative welfare social calling for development of a new product or service should driven by a corporate objective calling for growth, perhaps and on knowledge of available resources capital resources available from corporate as well as human and technological resources in the quality system audit department. Linkages, which are horizontal across departments, across regional offices, across manufacturing plants or divisions, require coordination and cooperation to get the organizational units all playing in harmony. For example, an organizational qualitative welfare social calling for introduction of a new product or service requires the combined efforts and thus coordination and cooperation among the quality system audit, the organizational development, and the manufacturing departments. Their formal educational levels tended to be high. Amongst this quality system audit, a distinction could be drawn between and those for whom their current organizational development was their first organization and the majority were novice organizational development managers. Regardless of the educated workers, a significant number had gained organizing before setting up their own organization. They can be contrasted with the remainder of the sample group who had been working more directly in production. Clearly, within this group, there is a sub set of growth oriented quality system audit whose propensity to undertake organizational qualitative welfare social quality system audit might be contrasted with those who were content with their current level of organizational development. The latter may well belong to that group of quality system audit often characterized as running lifestyle organization. From this overview of the selected developed manager's managers' characteristics and the strategies of the sampled organization, it is now possible to explore the extent to which these differing characteristics and strategies influence whether or not an organization engages in organizational qualitative welfare social. The organizational qualitative welfare social pay a significant attention regarding the introduction of new products and developing existing products, however, these developed organizations did not pay much attention to the ideas that was considered strange for the first glance. There was a significant relationship between organizational qualitative welfare social and developed manager's use to the strategy and creativity. The developed management support, independency and low organizational barriers had a significant positive effect on increasing organization ability to organizational qualitative welfare social. For organizations to be organizational qualitative welfare social strategy, they had to improve their working environment and delegate their employees more authorities by quality system audit. 


\section{Macrothink}

World Journal of Business and Management

ISSN 2377-4622

2015, Vol. 1, No. 1

However, concluded that the performance of the organization is highly affected by its organizational qualitative welfare social strategy and developed manager's creativity. The analysis and studies show that there existed positive relationship between organizational qualitative welfare social strategy, management perception, customer involvement, organizational qualitative welfare social information and creating a sustainable competitive advantage. Based on the results a number of recommendations were proposed and suggestions for future studies were made. Contribution is the kind in the region that tackles in a specific way the impact of strategy in organizational qualitative welfare social, management perception and support for the process of organizational qualitative welfare social strategy, perception and involvement in the process of organizational qualitative welfare social strategy and strategy in organizational qualitative welfare social information, on the potential of creating a sustainable competitive advantage for developed manager's institutions. In spite of this general awareness, such long-term organizational development, strategic-level planning of organizational development has been lacking in most organizations. The organizational development field is now giving high priority to developing organizational development metrics. The role of organizational development is to implement organizational qualitative welfare social. Effective organizational qualitative welfare social is one of the important factors in organizations success. There is a organizational development manager who argues that formal written planning may be inappropriate for the organizations but this seems a minority view. It can be argued that organizational qualitative welfare social is as important to organizations.

\section{References}

Aydin, S., Cetin, A., \& Ozer, G. (2007). The relationship between organizational qualitative welfare social and product development process and their effects on organization performance. Acad. Market. Stud. J., 11, 53-68.

Baker, S., Crockett, R. O., \& Capell, K. (1998). The cell phone as handheld miracle. Business Week, July 13. International European Business, Europe. Retrieved from http://www.businessweek.com/archives/1998/b3586149.arc.htm

Bank Ireland. (2010). Insights into distribution channel strategy in the retail banking sector: Customer focus as a key driver. Retrieved from http://www.fs-strategy.org

Barney, J. (1991). Organization resources and sustained competitive advantage. J. Manage., 17, 99-120. http://dx.doi.org/10.1177/014920639101700108

Bastic, M. (2004). Success factors in transition countries. Eur. J. Strategy Manage, 7, 65-79. http://dx.doi.org/10.1108/14601060410515655

Bharadwaj, S. G., Varadarajan, R., \& Fahy, J. (1993). Sustainable competitive advantage in service industries: A conceptual model and research propositions. J. Market., 57, 83-99. http://dx.doi.org/10.2307/1252221

Bolton, B., \& Thompson, J. (2000). Entrepreneurs, Talent, Temperament and Technique (pp. 65-97). London, Butterworth Heinemann. 
Bridge, S., O’Neill, K., \& Cromie, S. (1998). Understanding Enterprise, Entrepreneurship \& small Business (p. 124). London, Macmillan Business.

Brown, S. L., \& Eisenhardt, K. M. (1995). Product development: Past research, present findings and future direction. Acad. Manage. Rev., 20, 343-378.

Brown, S., \& Eisenhardt, K. (1998). Competing on the Edge (pp. 68-91). Harvard Business School Press,

Burns, P. (2001). Entrepreneurship and small Business (pp. 34-74). Basingstoke, Palgrave.

Calik, N., \& Balta, N. F. (2006). Consumer satisfaction and loyalty derived from the perceived organizational development of individual banking services: A field study in Eskişehir from Turkey. J. Quality system audit Services Market., 10, 135-149.

Chandy, R. K., \& Tellis, G. J. (2000). The incumbents curse? Incumbency, size and radical product strategy. J. Market., 64, 1-17. http://dx.doi.org/10.1509/jmkg.64.3.1.18033

Chell, E. (1985). The Entrepreneurial Personality: A Few Ghosts Laid To Rest. International small Business Journal, 3-38. http://dx.doi.org/10.1177/026624268500300303

Chell, E. (2001). Entrepreneurship: Globalization, Innovation and Development (p. 67). London, Thomson Learning.

Chell, E., Haworth, J., \& Brearley, S. A. (1991). The Entrepreneurial Personality (p. 167). London, Rutledge.

Cheng, C. J., \& Shiu, E. C. (2008). Re-strategy: The construct, measurement and validation. Technovation, 28, 658-666. http://dx.doi.org/10.1016/j.technovation.2007.08.002

Chiva-Gomez, R., Alegre-Vidal, J., \& Lapiedra-Alcami, R. (2004). A model of product design management in the Spanish ceramic sector. Eur. J. Strategy Manage., 7, 150-161. http://dx.doi.org/10.1108/14601060410534375

Christensen, C. M., \& Bower, J. L. (1996). Customer power, strategic investment and the failure of leading organizations. Strategic Manage. J., 17, 197-218. http://dx.doi.org/10.1002/(SICI)1097-0266(199603)17:3<197::AID-SMJ804>3.0.CO;2-U

Curran, J., \& Blackburn, R. (1994). Business planning and Local Economic Networks (pp. 31-49). London: Paul Chapman.

Daley, D. M., \& Vasu, M. L. (1998). Fostering organizational trust in North Carolina: The pivotal role of administrators and political leaders. Admin. Soc., 30, 62-84. http://dx.doi.org/10.1177/009539979803000105

Deakin, D., \& Freel, M. (2003). Entrepreneurship and Business planning (pp. 302-412). London, McGraw Hill.

Dekimpe, M. G., \& Hanssens, D. M. (1999). Sustained spending and persistent response: A new look at long-term organizational qualitative welfare social profitability. J. Market. Res., 36, 397-412. http://dx.doi.org/10.2307/3151996 


\section{I Macrothink}

World Journal of Business and Management

ISSN 2377-4622

2015, Vol. 1, No. 1

Driva, H., Pawar, K. S., \& Menon, U. (2000). Measuring product development performance in manufacturing organizations. Int. J. Prod. Econ., 63, 147-159. http://dx.doi.org/10.1016/S0925-5273(99)00007-9

Droge, C., Claycomb, C., \& Germain, R. (2003). Does knowledge mediate the effect of context on performance? Some initial evidence. Decision Sci., 34, 541-568. http://dx.doi.org/10.1111/j.1540-5414.2003.02324.x

Drucker, P. F. (1990). Managing the Non-Profit Organization: Practices and Principles. New York: Harper Collins.

Eisingerich, A. B., \& Bell, S. J. (2006). Relationship organizational qualitative welfare social in the quality system audit services industry: The importance of customer education, participation and problem management for customer loyalty. J. Quality system audit Services Market., 10, 86-97.

Ettlie, J. E. (1997). Integrated design and new product success. J. Operations Manage., 15, 33-55. http://dx.doi.org/10.1016/S0272-6963(96)00095-2

Evans, J. R., \& Lindsay, W. M. (1996). The Management and Control of Organizational development (3rd ed.). West Publishing Co., St Paul, MN.

Fegh-hi, F. N. (2001). Executive Management Process (pp. 1641-261). Islamic Azad University, Tabriz Branch, Iran.

Fegh-hi, F. N. (2003a). Permanent Management of Organization (1st ed., pp. 131-232). Tabriz, Iran: Frouzesh Publication.

Fegh-hi, F. N. (2003b). Strategic Structure of Organization Management Process (4th ed., pp. 150-325). Islamic Azad University, Tabriz Branch, Iran,.

Fegh-hi, F. N. (2009). Organization Strategic Plan compilation (1st ed., pp. 121-134). Tabriz, Iran: Frouzesh Publication.

Fegh-hi, F. N. (2011). Technology Management of Organization (2nd ed., pp. 34-341). Frouzesh Publication, Tabriz, Iran.

Fegh-hi, F. N. (2015), Active and Dynamic Management of Organization (3rd ed., pp. 20-149). Tabriz, Iran: Frouzesh Publication.

Fegh-hi, F. N. (2015). Strategic Management of Organization (2nd ed., pp. 101-190). Tabriz, Iran: Frouzesh Publication.

FIB. (1998). Uusinta tietoa suomalaisten asenteista biotekniikkaan. FIB, Suomen Bioteollisuus.

Fisher, A. (2002). Annie weighs in on executive coaching and untruths on resumes. Fortune Magazine, 13, 89.

Fowler, S. W., King, A. W., Marsh, S. J., \& Victor, B. (2000). Beyond products: New strategic imperatives for developing competencies in dynamic environments. J. Eng. Technol. Manage., 
17, 357-377. http://dx.doi.org/10.1016/S0923-4748(00)00029-1

Frewer, L., Rowe, G., Marsh, R., \& Reynolds, C. (2001). Public Participation Methods: Evolving and Operationalising an Evaluation Framework. UK Department of Health.

Friar, J. H. (1995). Competitive advantage through product performance strategy in a competitive market. J. Prod. Strategy Manage., 12, 33-42.

Fuller, S. (2000). The Governance of Science: Ideology and the Future of the Open Society. Buckingham - Philadelphia: Open University Press.

Goleman, D., Boyatzis, R., \& McKee, A. (2002). The New Leaders (pp. 78-199). London, Little, Brown.

Haddad, S., \& Algadeer, H. (2004). An empirical investigation on the impact of strategy within organizations on organizational qualitative welfare social strategy. Jordan. J. Applied Sci., 7, 77-95.

Hamel, G., \& Prahalad, C. K. (1994). Competing for the Future. Harvard Business School, Boston, London.

Hartley, J. L., Zirger, B. J., \& Kamath, R. R. (1997). Managing the buyer-supplier interface for on-time performance in product development. J. Operations Manage., 15, 57-70. http://dx.doi.org/10.1016/S0272-6963(96)00089-7

He, Z. L., \& Wong, P. K. (2009). Knowledge interaction with manufacturing clients and strategy of knowledge-intensive business services organizations. Strategy Manage. Policy Prac., 11, 264-278. http://dx.doi.org/10.5172/impp.11.3.264

Helfat, C. E., Finkelstein, S., Mitchell, W., Peteraf, M. A., Singh, H., Teece, D. J., \& Winter, S. G. (2007). Dynamic Capabilities: Understanding Strategic Chance in Organizations. Oxford, UK: Blackwell Publishing.

Henard, D. H., \& Dacin, P. A. (2010). Reputation for product strategy: Its impact on consumers. J. Prod. Strategy Manage., 27, 321-335.

Henningsen, C. (2002). Investing as if the world really mattered. Corporate Environmental Continuation, 9(2), 22-39. http://dx.doi.org/10.1016/s1066-7938(02)00007-6

Holak, S. L., \& Lehmann, D. R. (1990). Purchase intentions and dimensions of strategy: An exploratory model. J. Prod. Strategy Manage., 7, 59-73. Retrieved from http://www.birnbaumassociates.com/continuation-quality system audit.htm

Idwon, P. A., Alu, A., \& Adagunodo, E. R. (2002). The effect of information technology on the growth of the banking industry in Nigeria. Electronic J. Inform. Syst. Dev. Countries, 10, $1-8$.

Ireland, R. D., Hitt, M. A., \& Vaidyanath, D. (2002). Alliance management as a source of $\begin{array}{lllll}\text { competitive } \quad \text { advantage. } \quad J . & \text { Manage., } & \text { 413-446. }\end{array}$ http://dx.doi.org/10.1177/014920630202800308 
Irwin, A. (1995). Citizen Science: A Study of People, Expertise and Sustainable Development. London and New York, Routledge.

Irwin, A., \& Wynne, B. (1996). Introduction. Misunderstanding Science? The Public Reconstruction of Science and Technology (pp. 1-17). Cambridge, Cambridge University Press. http://dx.doi.org/10.1017/CBO9780511563737.001

Irwin, A., \& Wynne, B. (1996). Misunderstanding Science? The Public Reconstruction of Science and Technology. Cambridge: Cambridge University Press. http://dx.doi.org/10.1017/CBO9780511563737

Jansen, J. J. P., Van den Bosch, F. A. J., \& Volberda, H. W. (2006). Exploratory strategy, exploitative strategy, and performance: Effects of organizational antecedents and environmental moderators. Manage. Sci., 52, 1661-1674. http://dx.doi.org/10.1287/mnsc.1060.0576

Janssen, K. L., \& Dankbaar, B. (2008). Proactive involvement of consumers in strategy: Selecting appropriate techniques. Int. J. Strategy Manage., 12, 511-541.

Jantunen, A. (2005). Knowledge processing capabilities and strategy performance: An empirical study. Eur. J. Strategy Manage., 8, 336-349.

Johnson, S. (2001). The connected lives of ants, brains, cities and software (pp. 44-63). Penguin.

Jonason, A., \& Holma, B. (2004). Strategy pricing: A case of pricing for profits on the mobile internet. Int. J. Inform. Technol. Manage., 3, 105-115. http://dx.doi.org/10.1504/IJITM.2004.004788

Joss, S., \& Durant, J. (1995). Public Participation in Science - The Role of Consensus Conferences in Europe. London, Science Museum with the Support of the European Commissions Directorate General XII.

Kahn, K. B. (2001). Market orientation, interdepartmental integration and product development performance. J. Prod. Strategy Manage., 18, 314-323.

Kirby, D. A. (2003). Entrepreneurship (p. 82). Maidenhead, McGraw Hill.

Kleinschmidt, E. J., \& Cooper, R. G. (1991). The impact of product strategyness on performance. J. Prod. Strategy Manage., 8, 240-251.

Klüver, L., Nentwich, M., Peissl, W., Torgersen, H., Gloede, F., Hennen, L., Eijndhoven, J. V., Est, R. V., Joss, S., \& Bellucci, S. (2000). European Participatory Technology Assessment. Participatory Methods in Technology Assessment and Technology Decision-Making. Copenhagen, The Danish Board of Technology.

Knorr, A., \& Zigova, S. (2004). Competitive advantage through strategy pricing strategies: The case of airline industry. University Bremen, 93, 1-23.

Kosak, M. (2006). Development strategies for banks in Eastern European markets: The role 
of IT systems. Faculty of Economics, Ljubljana.

Kotler, P. (2002). Organizational qualitative welfare social Management, Analysis, Planning, Implementation and Control. New York, USA: Prentice-Hall.

Krajewski, L. J., \& Ritzman, L. P. (2002). Operations Management: Strategy and Analysis (6th ed.). New England: Addison-Wesley, Massachusetts.

Kuratko, D. F., \& Hodgetts, R. M. (2004). Entrepreneurship: Theory, Practice (p. 64). Mason, Ohio, Thomson South Western.

Kuwahara, T. (1997). Technology Foresight in Japan: A New Approach in Methodology and Analysis (pp. 87-93). Technology Foresight, NSTDA, Bangkok.

Lagrosen, S. (2005). Harnessing the creative potential among users. Eur. J. Strategy Manage., $8,424-436$.

Lane, P., Koka, B., \& Pathak, S. (2006). The reification of absorptive capacity: A critical review and rejuvenation of the construct. Acad. Manage. Rev., 31, 833-863. http://dx.doi.org/10.5465/AMR.2006.22527456

Latting, J., Beck, M., Slack, K., Tetrick, L., Jones, A., Etchegaray, J., \& N. da Silva. (2004). Promoting service organizational development and client adherence to the service plan: The role of top managements support for strategy and learning. Administration Social Work, 28, 29-48. http://dx.doi.org/10.1300/J147v28n02_03

Ledoux, J. E. (1993). Emotional memory systems in the brain. Behavior and Brain Research, 58, 112-215. http://dx.doi.org/10.1016/0166-4328(93)90091-4

Ledoux, J. E. (1994). Emotional memory and the brain. Scientific American, 108, 15. http://dx.doi.org/10.1038/scientificamerican0694-50

Leonard, D. (1995). Wellsprings of Knowledge: Building and Sustaining the Source of Strategy. Boston: Harvard Business School Press.

Li, H., \& Atuahene-Gima, K. (2001). Product strategy strategy and the performance of new technology ventures in China. Acad. Manage. J., 3, 1123-1134. http://dx.doi.org/10.2307/3069392

Linder, C., \& Seidenstricker, S. (2010). The Strategic Meaning of Ingredient Brands: A Resource-Based Analysis. http://dx.doi.org/10.3923/ajm.2010.1.16

Lukas, B. A., \& Ferrell, O. C. (2000). The effect of market orientation on product strategy. J. Acad. Market. Sci., 28, 239-247. http://dx.doi.org/10.1177/0092070300282005

Lyons, R. K., Chatman, J. A., \& Joyce, C. K. (2007). Strategy in services: Corporate culture and investment banking. California Manage. Rev., 50, 174-191. http://dx.doi.org/10.2307/41166422

Mahmod, J., Alsamydai, I,, Alnawas, A. M., \& Rodina, A. Y. (2010). The Impact of Organizational qualitative welfare social Strategy on Creating a Sustainable Competitive 
Advantage: The Case of Private Commercial Banks in Jordan. Asian Journal of Organizational Qualitative Welfare Social, 4, 113-130. Retrieved from http://scialert.net/abstract/?doi=ajm.2010.113.130

Martin, B. R. (1997). Technology Foresight as a Tool for Strategic Management. In Anderson, J., Fears, R., \& Taylor, B. (Eds.), Managing Technology for Competitive Advantage (pp. 131-147). London: Financial Times Healthcare.

Mason, C., \& Stark, M. (2004). What do investors look for Business Plan. International small Business Journal, 22, 3.

McAfee, R. P. (2002). Competitive Solutions: The Strategisties Toolkit (p. 260). Princeton University Press, Princeton.

McGovern, J., Lindemann, M., Vergara, M., Murphy, S, Barker, M. A., \& Warrenfeltz, R. (2001). Maximizing the impact of executive coaching: Behavioral change, organisational outcomes, and return on investment. Retrieved from http://www.mentors.ca/coachingnews.html

Mela, C. F., Jedidi, K., \& Bowman, D. (1998). The long-term impact of promotions on consumer stockpiling behavior. J. Market. Res., 35, 250-262. http://dx.doi.org/10.2307/3151852

Michael, M. (2001). Technoscientific Bespoking: Animals, Publics and the New Genetics. New Genetics and Society, 20(3), 205-224. http://dx.doi.org/10.1080/14636770120092985

Miettinen, R., \& Väliverronen, E. (1999). In Science and Technology We Trust: On the Public Understanding of Science in Finland. Biotechnology and Public Understanding of Science. Proceedings of the UK-Nordic Co-Operative Seminar Helsinki October 25-27, 1998, Publications of the Academy of Finland 3/99.

Minnow, N. (1996). Downsizing corporate responsibility. Public Relations Continuation, 2(3), 5 .

Mintzberg, H. (1994). The rise and fall of Strategic Planning (pp. 81-109). Prentice Hall International.

Mintzberg, H., Alstrand, B., \& Lample, J. (1998). Continuation Safari (pp. 23-67). The Free Press.

Monks, R. (2001). The New Global Investor (pp. 24-49). London: Capstone.

Montoya-Weiss, M. M., \& Calantone, R. J. (1994). Determinants of new product performance: A review and meta analysis. J. Prod. Strategy Manage., 11, 397-417.

Naffziger, D., \& Kuratko, D. (1991). An Investigation into the Planning In small Business. Journal of Business and Entrepreneurship, Fall, 21.

Nijs, V. R., Dekimpe, M. J., Seenkemp, J. B. E. M., \& Hanssens, D. M. (2001). The category demand effects of price promotions. Organizational qualitative welfare social Sci., 20, 1-22. 
http://dx.doi.org/10.1287/mksc.20.1.1.10197

Niva, M. (2002). Gene Technology in Food Production and Consumer Interpretations of Risks.

North, J., Blackburn, R., \& Curran, J. (1997). Reaching small Business and Enterprising Futures. London: Paul Chapman.

NSTDA. (1996). Important Future Technologies of Thailand. A Project Undertaken by Chiang Mai University, NSTDA, Bangkok.

Olivero, G., Bane, K. D., \& Kopelman, R. E. (1997). Executive coaching as a transfer of training tool: Effects on productivity in a public agency. Public Personnel Management, 26(4), 68.

Pauwels, K., Hanssens, D. M., \& Siddarth, S. (2002). The long-term effects of price promotions on category incidence, brand choice and purchase quantity. J. Market. Res., 39, 421-439. http://dx.doi.org/10.1509/jmkr.39.4.421.19114

Peer Sources Website. (n. d.). Retrieved from http://www.mentors.ca/coachingnews.html

Peters, T. (1988). Thriving on Chaos (p. 160). Book Club Associates.

Rarichandran, T. (2001). Strategy assimilation in the presence on knowledge barriers technology uncertainty and adoption risks. Acad. Manage. Proc., 79, 1-6. http://dx.doi.org/10.5465/APBPP.2001.6133676

Roberts, P. W., \& Amit, R. (2003). The dynamics of strategy activity and competitive advantage: The case of Australian retail banking, 1981 to 1995. Organization Sci., 14, 107-122. http://dx.doi.org/10.1287/orsc.14.2.107.14990

Rue, L., \& Ibrahim, N. (1998). Planning Sophistication and Performance in small Businesses. Journal of Small Business Management, 36, 97.

Rungtusanatham, M., \& Forza, C. (2005). Coordinating product design, process design, and supply chain design decisions part A: Topic motivation, performance implications and article review process. J. Operations Manage., 3, 257-265. http://dx.doi.org/10.1016/j.jom.2004.10.013

Saguy, I. S., \& Moskowitz, H. R. (1999). Integrating the consumer into new product development. Food Technol., 53, 68-73.

Sinkula, J. M. (1994). Market information processing and organizational learning. J. Market., 58, 35-45. http://dx.doi.org/10.2307/1252249

Smith, N. R. (1967). The Entrepreneur and His Organization (pp. 112-184). University of Michigan, Bureau of Business and Economic Research.

Song, M., \& Swink, M. (2002). Organizational qualitative welfare social-manufacturing join involvement across stages of new product development: Effect on success of radical vs. incremental strategy. Academy of Management Proceeding, 1-36. 


\section{Macrothink \\ World Journal of Business and Management \\ ISSN 2377-4622 \\ 2015, Vol. 1, No. 1}

http://dx.doi.org/10.5465/APBPP.2002.7517616

Speed, R., \& Smith, G. (1992). Retail financial services segmentation. Service Indus. J., 12, 368-383. http://dx.doi.org/10.1080/02642069200000045

Srinivasan, S., Pauwels, K., Silva-Risso, J., \& Hanssens, D. M. (2009). Product strategys, advertising and stock returns. J. Market., 73, 24-43. http://dx.doi.org/10.1509/jmkg.73.1.24

Stacey, R. D. (2000). Strategic Management and Organisational Dynamics (pp. 23-42). Prentice Hall.

Steele, R. S. (1977). Power motivation, activation and inspirational speeches. Journal of Personality, 45, 28-68. http://dx.doi.org/10.1111/j.1467-6494.1977.tb00592.x

Storey, D. J. (1994). Understanding the small Business Sector (p. 55). London, Rutledge.

Storey, D. J., Watson, R., \& Wynarczyk, P. (1989). Case Studies of 40 BP (p. 97). Research Paper 67, London, Department of Employment.

Strambach, S. (2001). Strategy Process and The Role of Knowledge-Intensive Business Services. In K., M. Kulicke, \& A. Zenker (Eds.), Strategy Networks: Concepts and Challenges in the European Perspective. Koschatzky, Physica-Verlag, USA.

Stutely, R. (2002). The definitive business plan (p. 43). London, Financial Times, Prentice Hall.

Tesluk, P. E., Vance, R. J., \& Mathieu, J. E. (1999). Examining employee involvement in the context of participative work environments. Group Organization Manage., 24, 271-299. http://dx.doi.org/10.1177/1059601199243003

\section{Copyright Disclaimer}

Copyright for this article is retained by the author(s), with first publication rights granted to the journal.

This is an open-access article distributed under the terms and conditions of the Creative Commons Attribution license (http://creativecommons.org/licenses/by/3.0/). 